\title{
TOKOH NYI POHACI SANGHYANG SRI DALAM WAWACAN SULANJANA DAN CARITA PANTUN SRI SADANA: TINJAUAN INTERTEKSTUALITAS JULIA KRISTEVA
}

\section{THE CHARACTER OF NYI POHACI SANGHYANG SRI IN WAWACAN SULANJANA AND CARITA PANTUN SRI SADANA: JULIA KRISTEVA'S INTERTEXTUALITY OVERVIEW}

\author{
Evi Fuji Fauziyah ${ }^{1}$ dan Ade Kosasih ${ }^{2}$ \\ ${ }^{1}$ Badan Pengembangan dan Pembinaan Bahasa, ${ }^{2}$ Universitas Padjadjaran \\ Pos-el: ${ }^{1}$ fuji.vi@gmail.com dan 2a.kosasih@unpad.ac.id \\ *)Naskah diterima: 30 Maret 2021; direvisi: 23 April 2021; disetujui: 2 Juni 2021
}

\begin{abstract}
Abstrak
Penelitian ini akan membandingkan cerita, tokoh, dan peristiwa antara teks dalam naskah Wawacan Sulanjana dan teks dalam Carita Pantun Sri Sadana. Kedua teks tersebut memiliki bentuk berbeda yaitu yang satu teks tertulis dan yang satu teks yang dituturkan secara lisan. Adapun teori yang digunakan yaitu teori intertekstualitas yang dikemukakan oleh Julia Kristeva. Secara genre, Wawacan Sulanjana dan Carita Pantun Sri Sadana bisa dikategorikan sebagai puisi. Disinyalir Wawacan Sulanjana menjadi salah satu bentuk transformasi dari Carita Pantun Sri Sadana. Adapun untuk membuktikan transformasi dan hipogram maka digunakan teori intertekstualitas Julia Kristeva. Berdasarkan hasil analisis didapatkan kesimpulan bahwa tema dalam kedua teks tersebut memiliki satu kesamaan yaitu tentang kehidupan masyarakat agraris di tanah Sunda. Adapun yang menjadi objek cerita yaitu seorang tokoh bernama Nyi Pohaci Sanghyang Sri. Setelah dibandingkan, ada sedikit perbedaan urutan peristiwa dalam cerita dan adanya tokoh-tokoh lain yang menyertai cerita di dalam teks Carita Pantun Sri Sadana, tidak disertakan dalam cerita Wawacan Sulanjana.
\end{abstract}

Kata kunci: intertekstualitas, wawacan, carita pantun, sunda, dewi sri

\begin{abstract}
This research will compare the stories, chadacters, and events in the text between the Wawacan Sulanjana manuscript and the text in the Carita Pantun Sri Sadana. The two texts have different forms, one is a written text and one is oral text. The theory used is the intertextuality theory proposed by Julia Kristeva. In genre, Wawacan Sulanjana and Carita Pantun Sri Sadana can be categorized as poetry. It is pointed out that Wawacan Sulanjana is a form of transformation of Carita Pantun Sri Sadana. As for proving the transformation and hypogram, Julia Kristeva's theory of intertextuality is used. Based on the results of the analysis, it can be concluded that the themes in the two texts have one thing in common, namely about the life of agrarian communities in Sundanese land. The story is based on one of the character, namely Nyi Pohaci Sanghyang Sri. After comparison, there is a slight different in the sequence of the events, and there are several characters who told in the Carita Pantun Sri Sadana were not involved in the Wawacan Sulanjana.
\end{abstract}

Keywords: intertextuality, wawacan, carita pantun, sundanese, dewi sri 


\section{PENDAHULUAN}

Wawacan Sulanjana adalah salah satu naskah Sunda yang berisi teks tentang mitologi padi, khususnya kisah Nyi Pohaci Sanghyang Sri. Penamaan judul Wawacan Sulanjana berasal dari kata "Wawacan", yakni sebuah genre sastra berbentuk puisi yang dikenal oleh masyarakat Sunda terutama pada abad ke-19, sedangkan "Sulanjana" mengacu kepada salah satu tokoh utama di dalam cerita yang bertugas melindungi padi dari serangan antagonis yaitu Sapi Gumarang, Kalabuat (babi hutan), dan Budug Basu (hama) yang di dalam teks digambarkan sebagai perusak tanaman padi.

Wawacan mulai dikenal masyarakat Sunda setelah masuknya pengaruh kebudayaan Jawa (terutama Mataram Islam) pada awal abad ke-17 (Adiwidjaja, t.t.; Salmun, 1963; Ekadjati, dalam Holil 2018). Penguasaan Mataram di Tanah Sunda selama kurang lebih 50 tahun telah memberikan pengaruh besar dalam bidang bahasa dan kesusastraan Sunda. Beberapa pengaruh di antaranya tampak pada teks dalam naskah-naskah yang bersifat kesusasteraan yang banyak ditulis dalam genre wawacan dan guguritan (Rosidi, 1995: 385). Genre wawacan masuk ke wilayah Sunda (melalui Keresidenan Priangan) menggunakan dua jalur yaitu jalur kabupaten dan jalur pesantren. Wawacan yang masuk melalui kabupaten biasanya menggunakan aksara Cacarakan, sedangkan yang masuk melalui jalur pesantren memakai aksara Pegon (Rosidi, 1966).

Teks Wawacan Sulanjana sangat populer di masyarakat Sunda. Kepopuleran itu bukan hanya dapat ditemui di desa-desa pertanian Sunda, seperti di Sumedang, Majalengka, atau Kuningan saja, tetapi juga dapat dicermati dari jumlah naskah Wawacan Sulanjana yang relatif banyak dan berasal dari berbagai daerah: dari timur sampai ke wilayah barat Jawa Barat. Berdasarkan penelusuran berbagai katalog, setidaknya ada tiga lembaga penyimpanan naskah yang (pernah) mengoleksi naskah Wawacan Sulanjana, yaitu: Perpustakaan Nasional RI, Jakarta (2 naskah), EFEO Bandung (3 naskah), dan Perpustakaan Universitas Leiden, Belanda (5 naskah). Di luar ketiga lembaga penyimpanan naskah itu, naskah Wawacan Sulanjana masih ada juga yang disimpan oleh pemilik naskah secara perorangan (Holil, 2018: 1).

Sejauh penelusuran yang telah dilakukan (Holil, 2018) meskipun cerita Wawacan Sulanjana sangat populer, namun alih aksara dan terjemahan naskah-naskah ini belum banyak dilakukan, khususnya Wawacan Sulanjana yang menjadi koleksi lembaga yang telah disebutkan. Kajian yang dilakukan Kalsum berupa skripsi (1983) dan Dina Darnia berupa skripsi (2004) bersumberkan pada naskah koleksi pribadi yang ada di masyarakat.

Adapun teks Wawacan Sulanjana yang dijadikan objek dalam tulisan ini adalah teks wawacan koleksi Perpustakaan Universitas Leiden yang sudah ditransliterasi oleh Munawar Holil (2019: 3) dengan kode (1) Wawacan Sulanjana (bernomor koleksi Cod. Or. 7612 atau Mal. 2568); (2) Wawacan Sulanjana (bernomor LOr. 7839 atau Mal. 2058); (3) Wawacan Sulanjana (bernomor koleksi LOr. 7851 atau Mal.2070; (4) Wawacan Sulanjana (bernomor koleksi LOr. 7926 atau Mal. 2132; (5) Wawacan Sulanjana (bernomor koleksi Cod. Or. 8633 atau Mal. 3136). Kelima naskah tersebut menggunakan aksara Pegon, adapun bahasa yang digunakan adalah bahasa Sunda. Naskahnaskah tersebut merupaka pemberian dari Prof. Dr. C. Snouck Hurgronje kepada Perpustakaan Leiden pada tahun 1936. Untuk titimangsa dalam naskah hanya ada satu yang mencantumkan tanggal, sedangkan 
dua diantaranya informasi hanya berdasarkan katalog yaitu:

a. Pada naskah (2) Wawacan Sulanjana (bernomor LOr. 7839 atau Mal. 2058) yang mana pada lembaran terkahir terdapat tulisan

'Wawatjan Solenjana
Ongeveer = het ex. Uit Tjiampea
Bandoeng 1896'

\section{Wawacan Sulanjana}

Tentang = mantan dari Ciampea

Bandung 1896

b. Pada naskah (3) LOr. 7851 (Mal 2070)

Naskah ini berasal dari Koleksi Snouck Hurgronje No. 75, salinan tahun 1894, berdasarkan naskah dari Ciampea, Bogor (Holil, 2018: 7).

c. Pada naskah (5) Cod. Or. 8633 (Mal. 3136)

Sampul halaman terbuat dari karton tipis berwarna biru seperti yang umumnya digunakan untuk sampul buku tulis. Alas naskah menggunakan buku tulis bergaris seperti buku "Letjes". Kondisi naskah masih bagus, aksara jelas dan dapat dibaca. Naskah ini disatukan dalam bundel yang sama dengan naskah-naskah bernomor koleksi: Cod. Or. 8630, Cod. Or. 8631, Cod. Or. 8632, Cod. Or. 8634, Cod. Or. 8633, Cod. Or. 8635, dan Cod. Or. 8637 (atau Mal. 31333140). Naskah ini berasal dari Koleksi Rinkes, ditulis pada 1321 H/ 1903 M (Holil, 2018: 9).

Carita pantun merupakan satu dari sekian banyak sastra lisan yang tersebar di masyarakat Sunda. Bentuk carita pantun berupa narasi monolog seorang juru pantun, yang menceritakan kisah-kisah yang dianggap suci dan sakral, kebanyakan berupa mitos berkisah tentang kerajaan Sunda dan tokoh-tokoh pada zaman dahulu. Dalam naskah Sunda kuno, Sanghyang Siksa Kandang Karesyan yang ditulis pada tahun 1518 masehi tercatat bahwa jika kita ingin bertanya tentang sebuah masalah tanyakanlah pada ahlinya, dan bila kita ingin mengetahui tentang carita pantun maka bertanyalah kepada juru pantun. "Hayang nyaho di pantun ma: Langgalarang, Banyakcatra, Siliwangi, Haturwangi; prepantun tanya." Yang artinya "bila ingin mengetahui tentang pantun, seperti Langgalarang, Banyakcatra, Siliwangi, Haturwangi; tanyalah juru pantun" (Fauziyah, 2014: 2).

Jika merujuk pada keterangan tersebut, bisa dipastikan Carita Pantun Sri Sadana memiliki teks yang lebih tua daripada Wawacan Sulanjana. Yang menarik dari kedua teks tersebut adalah adanya tokoh Sri yang disakralkan dan menjadi pusat penceritaan. Kristeva dalam Culler (1975) mengemukakan bahwa tiap teks itu merupakan mosaik kutipan-kutipan dan merupakan penyerapan (transformasi) teks-teks lain. Transformasi adalah teks yang muncul belakangan, sedangkan teks yang menjadi sumber acuan disebut hipogram.

Maka dari itu pendekatan penelitian yang digunakan dalam penelitian ini adalah pendekatan intertekstual. Pendekatan intertekstual membandingkan dua buah teks yang diduga memiliki keterkaitan. Dengan menggunakan intertekstual ini diharapkan mampu memunculkan perbandingan antar teks dan mendeskripsikan keterkaitan karakter tokoh, alur, dan latar pada Wawacan Sulanjana dan Carita Pantun Sri Sadana. Penulis juga menggunakan pendekatan intertekstual untuk menemukan hipogram dan transformasi dalam kedua teks tersebut. Data dalam penelitian ini adalah kutipan berupa kata-kata atau kalimat yang mendeskripsikan tentang tokoh, alur, latar, untuk mengetahui persamaan dan perbedaan dari kedua teks tersebut. 


\section{METODE PENELITIAN}

Metode yang digunakan di dalam penelitian ini yaitu metode deskriptif, metode ini melihat keterkaitan dua variabel melalui analisa data yang dikemukakan Nasir (2003: 54) bahwa metode deksriptif adalah pencarian fakta dengan interpretasi yang tepat, yang bertujuan membuat deskriptif, gambaran secara sistematis, faktual, akurat tentang fakta-fakta, sifat-sifat, serta hubungan antar fenomena yang diselidiki. Sumber data untuk penelitian ini yaitu teks yang terdapat di dalam teks Wawacan Sulanjana dan teks Carita Pantun Sri Sadana. Data dalam penelitian ini adalah kata, frasa, kalimat, dan isi keseluruhan teks cerita yang mencakup tentang tema, kejadian, dan tokoh dalam teks keduanya.

Teknik yang digunakan dalam menganalisis data yaitu pertama, mengidentifikasi data tokoh di dalam teks Wawacan Sulanjana dan Carita Pantun Sri Sadana. Kedua, mengidentifikasi kejadian di dalam teks. Ketiga, membandingkan teks, menentukan transformasi antar teks, dan menemukan hipogram. Keempat, membuat kesimpulan.

\section{LANDASAN TEORI}

Pendekatan intertekstual pertama kali diilhami oleh gagasan pemikiran Mikhail Bakhtin. Bakhtin adalah seorang filsuf Rusia yang mempunyai minat besar terhadap sastra. Bakhtin dikenal karena tiga teorinya yaitu: karnaval, konsep dialogis (polifoni), serta chronotope dan diskursus novelistik.

Kontribusi Julia Kristeva terhadap gagasan intertekstualitas sangat besar. Dia tidak hanya menciptakan kata intertekstualitas tetapi secara substansial menekankan pentingnya dinamika potensial yang ada di dalam teks. Teks bukanlah entitas yang tidak linier melainkan kombinasi teks yang heterogen. Teks apa pun sekaligus sastra dan sosial, kreatif dan budaya. Teks dibentuk secara budaya dan kelembagaan. Sebagian besar gagasan yang dikemukakan Kristeva merupakan pengerjaan ulang atau revisi gagasan Bakhtinian tentang interteksualitas. Bakhtin juga berpandangan bahwa teks tidak dapat dilepaskan dari tekstualitas sosiokultural yang melatarbelakangi penciptaan sebuah teks.

Julia Kristeva menciptakan istilah intertekstualitas. Meskipun intertekstualitas muncul sebagai konsep poststrukturalis, intertekstualitas ada sebagai fenomena universal yang menjelaskan interkoneksi komunikatif antara teks dan teks dan konteks. Namun, seperti yang diamati Zindziuviene dalam Raj (2015) ia masih "mempertahankan aspek mozaik, absorptif, dan transformatifnya" dalam wacana poststrukturalis. Dengan datangnya berbagai teori, intertekstualitas kini telah memperoleh makna yang lebih luas daripada apa yang telah dijelaskan Kristeva dalam karya terobosannya "Word, Dialogue and Novel".

Intertekstualitas menyatakan bahwa teks "tidak dapat eksis sebagai keseluruhan yang hermetis atau mandiri, sehingga tidak berfungsi sebagai sistem tertutup" (Worton dan Still, 1990). Penulis menyusun teks dengan membaca teks lain dan teks tersebut menjadi tersedia bagi audiens dalam proses membaca. Bhaktin menemukan dalam dialog Socrates sebagai bentuk novel paling awal, heteroglossia dan dialogisme, yang kemudian disebut Kristeva sebagai intertekstualitas. Kirsteva berasumsi bahwa sebuah teks disusun sebagai bermacammacam kutipan dan merupakan asimilasi dan perubahan dari kutipan lain. Intertekstualitas mengembalikan intersubjektivitas. Dalam "The Bounded Text", Kristeva membahas proses pembuatan teks di luar wacana yang sudah ada. Penulis tidak asli dan tidak membuat apapun dari teks mereka dari pikiran aslinya tetapi mengkompilasi dari teks yang sudah ada. Dia 
menjelaskan teks sebagai "permutasi teks, intertekstualitas dalam teks tertentu," "beberapa ucapan, diambil dari teks lain berpotongan dan menetralkan satu sama lain" (Kristeva, 1980).

Intertekstual yang digagaskan oleh Kristeva ada dalam sebuah ruang teks yang terdapat berbagai ujaran atau tuturan, yang diambil dari teks lain dan teks tersebut silang-menyilang dan menetralisir satu sama lain (Kristeva, 1980). Dengan kata lain, sebuah teks dikonstruksi atas beberapa komponen atau potongan tekstual yang dapat dilihat melalui karya tersebut. Potongan-potongan teks dalam satu teks tersebut tidak dapat dilihat sebagai satu hal yang terpisah, tetapi dimaknai sebagai satu kesatuan (Kristeva, 1980). Hal itu disebut ideologeme oleh Kristeva.

Kristeva memandang teks sebagai interaksi teks bukan sebagai entitas tunggal. Kemungkinan keterbukaan yang dimasukkan teks di dalamnya melepaskan kemungkinan melihat teks dari berbagai bidang. Klaim bahwa penulis saat menyusun teks terlibat dalam wacana dengan teks lain menunjukkan dinamika kreativitas yang menjelajah di luar subjek kreatif. Percakapan yang dilakukan penulis ini adalah dialog kreatif di mana makna diatur atau disusun, bukan diciptakan. Oleh karena itu, apa yang kita sebut sebagai makna teks menemukan karakterisasi yang lebih luas dan kompleks di luar apa yang tertulis dalam teks.

Bakhtin dalam Ratna (2006) berpendapat tidak ada teks yang benar-benar asli tanpa dipengaruhi oleh teks lain. Dalam penyimpangan dan transformasi pun model teks yang sudah ada tetap memainkan peranan kaitannya transformasi karya sastra. Hal tersebut merupakan proses pengalihan hubungan intertekstualitas untuk menemukan hubungan makna secara langsung maupun tak langsung. Kristeva dalam Ratna, (2006) berpendapat bahwa dinamika teks terletak dalam transformasi dari satu genre ke dalam genre lain baik sebagai negasi, oposisi, sinis, lelucon, parodi maupun sebagai apresiasi, afirmasi, nostalgia, dan jenis pengakuan estetis lain yang secara keseluruhan berfungsi untuk menemukan makna-makna baru dan orisinil. Transformasi tidak terbatas semata-mata dalam kerangka literer, tetapi juga meluas dalam karya seni yang lain. Dalam kerangka multi kultural, aktivitas intertekstual berfungsi untuk membangktikan kesadaran masa lampau, baik sebagai citra primordial maupun nostalgia atau disebut teks pastiche.

Untuk melakukan kegiatan transformasi atau perubahan dari teks satu ke teks yang lain, pengarang tidak semata-mata melakukan duplikasi atau menyalin, menyadur atau menterjemahkan. Bentuk transformasi ditandai dengan suatu proses tertentu baik secara langsung ataupun tak langsung menggambarkan tanggapan pengarang terhadap teks asing yang diambilnya sebagai latar karya sastranya. Bagaimanapun, gagasan Bakhtin tentang dialogisme didasarkan pada bagaimana manusia menggunakan bahasa dalam situasi sosial tertentu, tetapi Kristeva lebih banyak berpikir dalam konteks teks dan tekstualitas. Keduanya sampai pada titik teks tidak dapat dilepaskan dari tekstualitas sosial atau budaya yang merupakan titik balik teks itu dibuat. Teks sosial dan teks sastra saling terkait tak terpisahkan.

\section{HASIL DAN PEMBAHASAN}

Pantun dalam masyarakat Sunda adalah simbol budaya, yakni alam pikiran masyarakat Sunda. Pantun bukan hanya simbol, tetapi simbol sakral. Pantun tidak dapat diceritakan sehari-hari. Pantun diceritakan dalam sebuah ritual, tempat ritual, waktu ritual dan tema ritual. Tema ritualnya adalah menghadirkan tokoh-tokoh pahlawan budaya Sunda di masa lampau, tingkah 
laku dan kisah hidup mereka merupakan teladan untuk menyatukan etos sosial (Sumardjo, 2006: 50).

Dalam proses pemantunannya, pantun Sunda hanya diceritakan pada waktu tertentu saja, pada saat ritual. Misalnya, Carita Pantun Sri Sadana ini, hanya diceritakan khusus ketika musim panen. Ajip Rosidi mengatakan dalam bukunya (1970: X), "lakon Sri Sadana ini merupakan salah satu lakon favorit Ki Atjeng Tamadipura. Sedangkan dikisahkannya dalam musim panen. Seperti diketahui pertunjukan pantun erat bertalian dengan ritual padi: sehabis panen sesudah mendudukan padi di dalam rengkiang".

\section{Tokoh Sri dalam Wawacan Sulanjana}

Tokoh dalam Wawacan Sulanjana dibagi ke dalam dua kelompok, yaitu tokoh sebagai pelaku utama dan pelaku tambahan. Pelaku utama cerita ini adalah Dewa Guru, Sulanjana, dan Sapi Gumarang. Sedangkan pelaku tambahannya adalah Panji Narada, Dewa Anta, para dewa, Prabu Siliwangi, Dewi Nawang Wulan, Ki Semar, Budug Basu, Kalabuat, dan sebagainya. Inti cerita dari Wawacan Sulanjana adalah tentang upaya Sulanjana menyelamatkan dan melindungi Nyi Pohaci Sanghyang Sri yang sudah berbentuk padi.

Tokoh Nyi Pohaci Sanghyang Sri yang menjadi objek cerita merupakan anak yang lahir dari telur yang berasal dari air mata Naga Anta. Di dalam teks Wawacan Sulanjana, penyebutan Nyi Pohaci Sanghyang Sri biasa disebut Nyi Dewi Puhaci, kadang juga Nyi Pohaci.

Nyi Pohaci Sanghyang Sri dibesarkan di kahyangan dan disusui oleh Dewi Uma istri Dewa Guru. Namun, ketika anaknya mulai agak besar tapi masih dalam proses menyusui, Yang Wenang, seorang dewa yang derajatnya lebih luhur dari Dewa Guru memiliki firasat bahwa Dewa Guru akan memperistri anak ini. Berikut cuplikanya dalam Wawacan Sulanjana, Pupuh ke 3, Kinanti, baris 2-7 :

d. Aya deuinu kacatur, gagah sarta leuwih sakti, jenengan Nyang Deiwa Wenang, anu gagah taya tanding, mikir sajeroning manah, eita ka Deìi Puhaci.

Ada lagi yang diceritakan, gagah dan lebih sakti, namanya Nyang Dewa Wenang, yang gagah tiada tamding, berpikir di dalam hati, memusatkan pikirannya pada Dewi Pohaci.

e. Sabab eita enggeus tangtu, ku Deìwa Guru dikawin, ku sabab leuwih geulisna, eita Nyi Deiwi Puhaci, ayeuna kuma petana, sangkan ulah tulus kawin.

Sudah tentu akan dikawin oleh Dewa Guru, karena lebih cantik, itu Nyi Dewi Pohaci, sekarang bagaimana caranya, supaya (mereka) gagal kawin.

f. Tangtuna ngaruksak hukum, eita lamun tulus kawin, geureuhana Yang Parmeisti ku saba geus jadi anak, disusuan Nyi Puhaci, ku ngaran Nyi Deiwi Uma, geureuhana Yang Permeisti.

Karena tentu saja merusak hukum, jika sampai terjadi kawin, istrinya Yang Parmesti sudah menganggapnya anak, disusuinya Nyi Pohaci, oleh orang bernama Nyi Dewi Uma, istrinya Yang Permesti.

g. Ti dinya Yang Wenang tuluy, nyandak buah huldi, ..... eita buah, ka Deìvi Puhaci, ti dinya buah didahar, langkung ni'mat Nyi Puhaci. Dari situ Yang Wenang, lalu mengambil buah huldi, yaitu buah, (yang diberikan) kepada Dewi Pohaco, lalu buahnya dimakan, betapa menikmatinya Nyi Pohaci.

h. Geus kitu teu kersa nyusu, eita Nyi Deizwi Puhaci ${ }^{1}$, sabab eita kaeidanan, hayang deui buah huldi, hanteu kersa barang dahar, beurang peuting nangis.

Setelah itu tidak mau menyusu (kepada ibunya), itu Nyi Dewi Puhaci, karena 
tergila-gila, ingin lagi makan buah holdi, tidak mau makan minum, siang malam hanya menangis saja.

i. Caritana lajeng ngangluh, eita Nyi Deiwi Puhaci, langkung banget kasawatna, sagala tamba teu matih, ti dinya dongkap ka ajal, pupus Nyi Deiwi Puhaci.

Lalu dia mengeluh, dia Nyi Dewi Pohaci, semakin menjadi sakitnya, segala obat tidak manjur, lalu dia menemui ajalnya, meninggal Nyi Dewi Puhaci.

Setelah Nyi Pohaci meninggal lalu Dewa Guru memerintahkan Aki Bagawat untuk mempersiapkan ruangan kubur untuk mengubur jasadnya. Ketika mayat sudah dimandikan, disalatkan dengan tertib, lalu mayatnya dikuburkan. Dewa Guru memberi amanat kepada Bagawat untuk menjaga kuburannya. Setiap Jumat Aki Bagawat menyapu bersih kuburannya, tidak ada sampah atau daun satu lembar pun, kuburannya rapih bersih. Lama-lama dari kuburannya tumbuh berbagai macam tanaman. Berikut ini kutipannya dalam Wawacan Sulanjana, Pupuh 3, Kinanti baris 13 - 20:

1. Lila-lila tina kubur, bet aya kalapa jadi, jeung tina lebah sirahna, buah kalapa teu sami, heijo beureum rupa buah, warna-warna hanteu sami.

Lama-lama dari kuburannya, tumbuh pohon kelapa, dari pas kepalanya, tumbuh juga buah kelapa yang tidak sama, hijau merah rupa buah, warnawarnanya tidak sama.

2. Salebah panon katuhu, eita pareì anu jadi, sarta ngan saranggeuy pisan, buahna eita teu sami, aya beureum aya bodas, buluna nya kitu deui.

Di sebelah mata kanan, ada padi yang tumbuh, hanya satu tangkai, buahnya juga tidak sama, ada yang merah ada yang putih, bulunya pun juga begitu.

3. Aya anu panjang bulu, sawareih aya nu gundil, tina lebah naon keinca, bijil parei beureum eusi, buluna sawareih aya nu gundil, tina lebah panon, buluna nya kitu pisan, aya panjang aya gundil.

Ada yang panjang bulu, ada yang gundul, dari sebelah mata kiri, keluar padi merah berisi, sebagian bulunya gundul, dari pas mata, bulunya ya begitu, ada yang panjang ada yang gundul.

4. Aya anu beureum bulu, sawareih aya nu putih, aya nu koneing rupana, aya anu hideung kulit, anu jadi lebah mata, ketan saranggeuy bijil.

Ada yang merah berbulu, sebagian ada yang putih, ada yang kuning rupanya, ada yang hitam kulitnya, yang tumbuh pas mata, beras ketan satu tangkai tumbuh.

5. Bulu ketan gei nya kitu, aya panjang aya gundil, eusina nya kitu pisan, //13// aya hideung aya putih, aya nu beureum rupana, eusina kabeih teu sami.

Bulu ketan juga begitu, ada yang panjang ada yang gundul, isinya juga begitu, ada yang hitam ada yang putih, ada juga yang merah rupanya, isinya semua tak sama.

6. Ti lebah pingping katuhu, haur cucuk anu jadi, ti lebah pingping ti keinca, haur temen haur geulis, ti lebah bitis ti keinca, awi tali anu jadi.

Dari sebelah paha kanan, bambu duri bertumbuh, dari sebelah paha kiri, tumbuh bambu haur temen dan haur geulis, dari betis sebelah kiri, tumbuh bambu tali.

7. Ti lebah bitis katuhu, awi teman anu jadi, eita perkara wartana, jadi areuy bulat-beulit, buluna jadi sagala, cukup nu aya di bumi.

Dari betis sebelah kanan, bambu temen tumbuh, adapun urat nadinya, menjadi sembung rambat yang menjulat jalit.

8. Sakabeih taya nu kantun, sapangeusi jagat bukti, sipat rupa nu dicekel, hanteu aya anu kari, ki Bagawat ngadeuheusan, uninga ka Yang Permeisti. 
Semua tidak ada yang ketinggalan, seluruh jagat menjadi buktu, sifat dan rupa yang digenggam, tidak ada yang tertinggal, Ki Bagawat menghadap, memberitahukannya kepada Yang Permesti.

Ki Bagawat menghadap kepada Dewa Guru menceritakan atas apa yang terjadi di kuburan Nyi Pohaci Sanghyang Sri. Setelah melihat langsung kuburannya lalu Dewa Guru memerintahkan Ki Bagawat untuk membawa rupa-rupa benih tanaman tersebut ke Pakuan, harus diberikan kepada Prabu Siliwangi. Benih dan surat tersebut lalu dibaca oleh Raja Pakuan, kemudian ia memerintahkan seluruh ponggawa dan rakyatnya untuk menanam benih. Seluruh benih yang diberikan tumbuh subur. Dewa Guru lalu mengutus Semar untuk menjaga sawah dan tumbuhan yang subur tersebut.

Kesuburan tanah Pakuan dan hasil panennya yang melimpah sampai ke telinga seseorang nahkoda yang bernama Dempu Awang. Dia menghitung uang sebanyak tiga ratus real, untuk membeli padi di pakuan. Namun, Prabu Siliwangi menolak menjual beras tersebut, karena benihnya dari Dewa Guru, jadi beras tersebut adalah milik Dewa Guru. Lalu Dempu Awang sakit hati dan dia bertemu dengan Sapi Gumerang. Sapi Gumerang adalah nama tokoh antagonis di dalam Wawacan Sulanjana, sementara dalam Carita Pantun Sri SadanaCarita Pantun Sri SadanaCarita Pantun Sri Sadana tokoh ini disebut Sapi Gumarang.

Selanjutnya dikisahkan Sapi Gumarang datang ke Pakuan dan merusak tanaman yang ada di sana terutama padi. Dia bersama dengan Kala Buwat dan Budug Basu menyerang padi dengan berbagai cara. Diantaranya dengan membuat angin, mendatangkan hama, binatang seperti tikus, dan bahkan babi hutan. Melihat kekacauan dan hancurnya Nyi Pohaci Sanghyang Sri, kemudian Sulanjana dan kedua adiknya diperintahkan Yang Wenang untuk melawan Sapi Gumarang.

Sapi Gumarang sangat marah serta merasa malu kepada Dempu Awang. Beberapa kali padi dirusak, lalu "disehatkan" lagi oleh Sulanjana. Akhirnya Sapi Gumarang mengajak Sulanjana untuk berperang tanding. Namun, ternyata, Sapi Gumarang kalah, bahkan selanjutnya dia mengucapkan janji akan mengabdi kepada Sulanjana dan akan menjaga serta memelihara padi, asal setiap mulai bertanam padi nama dirinya dan kedua anaknya, Kala Buwat dan Budug Basu harus "dipanggil", baik secara batin maupun dengan mengucapkan mantra mulia menanam padi. Selain itu, juga harus disediakan daun paku di pepohonan sebagai syarat ketika menanam padi. Pertarungan antara Sapi Gumarang dan Sulanjana ini berlangsung lama dan dikisahkan dalam berbagai baris pupuh. Mungkin ini menjadi salah satu alasan judul dari Wawacan Sulanjana.

\section{Tokoh Sri dalam Carita Pantun Sri Sadana}

Tokoh Sri dalam Carita Pantun Sri Sadana (selanjutnya disingkat CPSS) tidak hanya satu orang, tetapi ada dua nama Sri dalamnya. Tokoh yang pertama adalah tokoh Sri Sadana yang bersaudara dengan Jaka Sadana dan Rambut Sadana. Mereka bertiga adalah anak yang berasal dari air mata Gusti Allah. Tokoh Sri yang kedua yaitu Nyi Pohaci Sanghyang Sri yang berasal dari air mata Naga Anta. Baik Sri Sadana ataupun Nyi Pohaci Sanghyang Sri, keduanya memiliki kisahnya masing-masing dan yang menarik keduanya juga yang mengakibatkan munculnya tanaman di dunia. Berikut ini kejadian tumbuhnya tanaman yang disebabkan oleh tokoh Sri Sadana:

yen sri sadana parantos sedeng rumaja putri

kinten yuswa lima welas taun 
datang tangara ti nu kawasa

kareseban

bijil ciciri

bijil kotoran

clak murag kana jagat kotoran sri sadana

katingali ku nini jeung aki

lila ti lila

pelentung aya nu jadi

tuluy bae dipiara

dimumule dihade-hade

bahwa sri sadana sudah masuk usia remaja putri

kira-kira usia lima belas tahun

datang berita dari yang kuasa

menstruasi

keluar ciri

keluar kotoran

menetes ke bumi darah sri sadana

terlihat oleh nini dan aki

lama-lama

kemudian ada yang tumbuh

lalu dipelihara

dilestarikan dengan baik

(CPSS, 1970: 22)

Lalu kelanjutannya, setelah kejadian darah menstruasi yang turun ke bumi, maka tumbuh berbagai tanaman palawija, serealia, dan rempah. Disebutkan diantaranya ada gadung, gandrung, jagung, jagung kecil, hanjere, hanjeli, sekul, kunyit, dan terigu (gandum).

kanyataanna kajadian kabuktian kotoran sri sadana teh

ngajadi gadung, gandrung, jagong,

jagong leutik, hanjere, hanjeli,

sekul, kunyit, sareng tarigu kenyataan dari kejadian itu terbukti kotoran sri sadana menjadi gadung, gandrung, jagung, jagung kecil, hanjere, hanjeli, sekul, kunyit, dan terigu (CPSS, 1970: 22)

Jadi proses kejadian yang melibatkan Sri Sadana tidak menunggu dia meninggal terlebih dahulu, tetapi tanaman itu tumbuh dari darah yang menetes ke bumi. Lain halnya dengan Nyi Pohaci Sanghyang Sri, dalam CPSS tanaman padi-padian tumbuh dari kuburannya. Akibat melakukan perbuatan suami istri, kakak beradik Nyi Pohaci dan Bangbang Kusiang dipisahkan. Dewa Guru marah dan Bangbang Kusiang dibuang ke Tanah Aceh. Karena ditinggal kekasihnya, Nyi Pohaci akhirnya jatuh sakit dan meninggal. Nawang Wulan diperintah Raja Pajajaran menghadap Dewa Guru dan bertanya harus bagaimana dengan mayat Nyi Pohaci. Maka diperintahkanlah mayatnya di kuburkan di Tegal Cikahuripan, makamnya harus dijaga Aki Nini Oma yang kemudian diangkat dan diubah namanya menjadi Aki Bagawat Sangsri dan Nini Bagawat Sangsri. Dari kuburannya tumbuh berbagai macam tanaman. Berikut kutipan teks dalam CPSS:

di tanah pakuburan tea

pelentung aya nu jadi

angenna ngajadi pare ketan

rupa-rupa ketan sarupana sacangci

panon bobodasna jadi pare bulu

bodas nu kenca jadi alot

nu bereum jadi pare gintung bereum

nu konengna jadi pare sari kuning

hihideungna pare gintung hideung

bulu panon ngajadi bulu pare

dari tanah kuburan (Nyi Pohaci Sanghyang Sri) 
mulai ada yang tumbuh

lambungnya menjadi padi ketan

rupa-rupa beras ketan yang brukuran sacangci

bagian mata yang putih menjadi padi bulu

bagian putih yang kiri jadi tumbuhan alot

yang merah jadi beras merah

yang kuning jadi berar sari kuning

hitamnya jadi padi gintung hitam

bulu mata menjadi bulu padi

mastaka ngajadi kalapa

pangambung jadi bawang bereung bawang bodas

baham jeung tapangeusi baham

jadi rupa-rupa tatangkalan anu bubuahanana raos diteda

kepala jadi kelapa

hidung menjadi bawang merah bawang putih

mulut dan isi mulut

menjadi rupa-rupa tanaman dan buahbuahan yang enak dimakan

panangan ruasan handap jadi tangkal kawung

pepeteuyan jadi tangkal peteuy

bulu saluar awak jadi lalab nu raos diteda

uratna jadi areuy-areuyan

pingping jadi awi surat

cecekolan jadi jengkol

....

tangan bagian bawah jadi pohon enau

lengan menjadi pohon petai

bulu di tubuh bagian luar menjadi

lalaban yang enak dimakan

urat menjadi pohon areuy paha menjadi bambu surat

cecekolan (lutut bagian belakang) men-

jadi jengkol

Dalam CPSS tanaman yang tumbuh dari kuburan Nyi Pohaci Sanghyang Sri benarbenar detail dari atas kepala hingga ujung kaki yang menjadi berbagai tanaman yang bisa dimakan baik itu padi, buah-buahan, dan bambu. Sementara di dalam Wawacan Sulanjana hanya disebutkan beberapa saja yang berhubungan dengan padi dan palawija, makanan pokok orang Sunda.

Kisah selanjutnya akan masuk ke tokoh yang bernama Sulanjana. Dalam CPSS juga merupakan anak dari ibu pertiwi. Sulanjana, Talimenar, Talimenir lahir dari ibu pertiwi saat ia mengandung dan menerima tetesan sir Dewa Guru. Sulanjana dalam CPSS bertarung melawan Bangbang Kusiang, saudara kembarnya Nyi Pohaci Sanghyang Sri. Sampai di Tanah Pajajaran, Bangbang Kusiang melihat kuburan Nyi Pohaci Sanghyang Sri dan mengambil padi segenggam padinya dipegang dan diciumi. Melihat hal ini Raden Jaka Sulanjana yang diperintah untuk menjaga padi mencoba menangkap Bangbang Kusiang namun dihalangi oleh Jaka Sela dan Jaka Pamor yang akhirnya mati di tangannya. Dari kuburan mereka berdua tumbuh besi dan baja. Bangbang Kusiang kembali ke Tanah Aceh, setibanya di sana ia bunuh diri di hadapan Raja Aceh. Melihat hal ini, Dewa Wisnu yang berada di Kahyangan menangis hingga air matanya jatuh ke bumi dan menjadi Jaka Sabeulah. Kuburan Bangbang Kusiang yang ada di Aceh, menjadi benih emas dan perak.

Budugbasu meminta izin ke kahyangan untuk melamar Nyi Pohaci, ia menghadap Dewa Guru, dan di sana ia mendapat kabar bahwa Nyi Pohaci telah mati. Ia turun ke bumi menemui Aki dan Nini Bagawat Sangsri dengan digiring malaikat Kalamula dan Kalamuntir. Di depan kuburan Nyi 
Pohaci, Budugbasu berkeliling 7 kali lalu mati. Sapi Gumarang merasa kehilangan Budugbasu, lalu ia mencarinya dan menemukan Budugbasu telah menjadi berbagai macam hama. Kemudian Sapi Gumarang memelihara hama-hama tersebut dan juga memelihara Kalamula yang berganti nama menjadi Ki Darweng yang bertugas menjaga hama di darat dan Kalamuntir yang berganti nama menjadi Ki Kaliwengkang yang bertugas menjaga hama di air.

Sawah-sawah di Pajajaran sudah mulai menguning dan tiba waktunya untuk dipanen. Dewa Guru dan Dewi Uma turun ke bumi menyamar menjadi burung pipit, dan mematuk-matuk padi, artinya padi harus dipipit atau dipanen. Semar dan anak-anaknya diganggu dan diajari membuat air nira dan gula kawung. Aki dan Nini Bagawat Sangsri memetik padi. Negara Pajajaran subur makmur, Nyi Pohaci menjalankan tugasnya dengan baik yaitu memajukan kehidupan manusia.

\section{Perbedaan Cerita dalam Wawacan Sulanjana dan Carita Pantun Sri Sadana}

Tema yang terkandung dalam teks Wawacan Sulanjana adalah asal mula terjadinya tumbuhan padi dan tanaman lainnya. Disebutkan bahwa padi berasal dari kuburan Puhaci, kemudian ditanam di Pakuan. Jadi negeri yang pertama kali mengenal padi adalah Pakuan di bawah pimpinan Prabu Siliwangi. Sedangkan dalam Carita Pantun Sri Sadana negara yang menjadi tempat pertama kali mengenal padi adalah Pajajaran. Namun yang menarik istri dari raja namanya sama yaitu Dewi Nawang Wulan. Beberepa perbedaan lain dalam Wawacan Sulanjana dan CPSS bisa dirunut sebagai berikut.

1. Buah Khuldi

Di dalam Carita Pantun buah khuldi diberikan kepada Nyi Pohaci Sanghyang Sri dan Bangbang Kusiang, lalu mereka diturunkan ke bumi, dan hidup di bumi.
Proses meninggalnya Nyi Pohaci Sanghyang Sri tidak mau makan dan minum karena ditinggalkan oleh kakaknya ke Aceh.

Di dalam Wawacan Sulanjana, Nyi Pohaci diberi buah khuldi saat masih menyusui kepada Dewi Uma, lalu dia menangis karena tidak mau minum susu dan mau makan buah khuldi saja. Akhirnya, Nyi Pohaci meninggal dan mayatnya diturunkan ke bumi diurus oleh Aki Bagawat.

2. Sulanjana

Tokoh Sulanjana dalam Wawacan Sulanjana adalah anak ibu pertiwi yang berasal dari air mani Dewa Guru yang jatuh ke bumi, kemudian ia menjelma menjadi lawan Sapi Gumarang, dan anak buahnya Budug Basu dan Kalabuat. Dalam wawacan, terjadi pertempuran hebat antara keduanya.

Sementara itu, edangkan tokoh Sulanjana dalam CPSS hanya berkisah saat ia menemui ayahnya yaitu Dewa Guru dan saat berduel dengan Bangbang Kusiang. Jadi, Sulanjana dalam CPSS tidak menjadi tokoh utama.

3. Tokoh Pelengkap

Dalam Wawacan Sulanjana tokoh yang disebutkan antara lain Dewa Guru, Panji Narada, Dewa Anta, Sulanjana, Nyi Pohaci Sanghyang Sri, Sapi Gumarang, Budug Basu, Nini dan Aki Bagawat, keluarga Semar, Prabu Siliwangi, dan Dewi Nawang Wulan.

Sementara itu, dalam CPSS selain tokoh-tokoh yang disebutkan tadi, ada juga tokoh lain yang bercerita dan diceritakan. Diantaranya adalah kisah Sri Sadana, Jaka Sadana, Rambut Sadana. Lalu kisah Lembu Wulung dan Idajil, Jaka Sabeulah, Raja Majapait dan Dewi Sukraba, Anggana Anggani Angganiah, Raja Aceh, dan Jaka Sela Jaka Pamor. 
Dari perbandingan tokoh di atas bisa dilihat bahwa penulis Wawacan Sulanjana hanya mengambil bagian inti tokoh yang berhubungan dengan kisah Nyi Pohaci Sanghyang Sri saja. Mulai dari terbentuknya tanaman yang diringkas, pemilihan tokoh, dan latar cerita hal ini membuktikan wawacan menjadi teks yang bertransformasi dari carita pantun. Dengan kata lain CPSS menjadi hipogram atau teks awal dari Wawacan Sulanjana.

\section{PENUTUP}

Berdasarkan hasil analisis maka didapatkan kesimpulan bahwa tema dalam teks Wawacan Sulanjana dan Carita Pantun Sri Sadana tersebut memiliki satu kesamaan yaitu tentang kehidupan masyarakat agraris di tanah Sunda. Sebuah teks dikonstruksi atas beberapa komponen atau potongan tekstual dapat dilihat melalui karya Wawacan Sulanjana. Potongan-potongan teks CPSS dalam teks Wawacan Sulanjana tidak dapat dilihat sebagai satu hal yang terpisah, tetapi dimaknai sebagai satu kesatuan.

Cerita dalam teks Wawacan Sulanjana dan CPSS keduanya didasarkan pada salah satu tokoh yakni Nyi Pohaci Sanghyang Sri. Namun, ada sedikit perbedaan urutan peristiwa dan tokoh-tokoh lain yang menyertai cerita di dalam teks. Kompleksitas tokoh, latar, cerita dalam CPSS menjadi bukti bahwa CPSS menjadi teks asal yang selanjutnya bertransformasi menjadi Wawacan Sulanjana. Tokoh-tokoh dalam CPSS ini disusun berdasarkan alur dan kapan si tokoh keluar. Jadi susunannya berurutan dari yang petama kali diceritakan sampai yang terakhir menjadi subjek penceritaan.

\section{DAFTAR PUSTAKA}

Adiwidjaja, R.I. t.t. Kasusastran Sunda II. Jakarta: J.B. Wolters -Groningen.

Culler, Jonathan. 1975. Structuralist. Structuralism, Linguistic and the Study of
Literature. London: Routledge and Kegan Paul.

Dina Darnia. 2004. “Kajian Struktur jeung Ajen Budaya Naskah Wawacan Sulanjana". Bandung: FPBS Universitas Pendidikan Indonesia.

Ekadjati, Edi S. 1984. "Sejarah Sunda" dalam Masyarakat Sunda dan Kebudayaannya. Bandung: Girimukti Pasaka, hlm.77-123.

Fauziyah, Evi Fuji. 2014. Carita Pantun Sri Sadana: Kajian Strukturalisme Levistrauss. Skripsi. Universitas Padjadjaran.

Holil, Munawar. 2018. Wawacan Sulanjana. Jakarta: Perpustakaan Nasional Republik Indonesia.

Kalsum dan Etti Rochaeti. 2005. Sastra Ritual, Wawacan Batara Kala, Wawacan Sulanjana. Jakarta: Dunia Pustaka Jaya.

Kristeva, Julia. 1980. Desire in Language a Semiotic Approach to Literature and Art. Oxford: Basil Blackwell.

Raj, P. P. E. 2015. Text/Texts: Interrogating Julia Kristeva's Concept of Intertextuality. Ars Artium, 3, 77.

Ratna, Nyoman Kutha. 2011. Teori, Metode, dan Teknik Penelitian Sastra. Yogyakarta: Pustaka Pelajar.

Rosidi, Ajip. 1966. Kesusastraan Sunda Dewasa Ini. Jatiwangi: Tjupumanik.

Rosidi, Ajip. 1995. "Kasusastraan Sunda" dalam Sastera dan Budaya: Kedaerahan dalam Keindonesiaan. Jakarta: Pustaka Jaya. hlm. 376-411.

Salmun, M.A. 1963. Kandaga Kasusastran. Cetakan ke-2. Bandung/Jakarta: Ganaco N.V.

Sumardjo, Jakob. 2006. Khazanah Pantun Sunda: Sebuah Interpretasi. Bandung: Kelir.

Worton, Michael dan Judith Still. 1990. Intertextuality and Practices. New York: Manchester University Press. 